\title{
Nest site characteristics of the Great-spotted Woodpecker in a bottomland riparian forest in the presence of invasive tree species
}

\author{
Gábor ÓNODI* \& Dániel WINKLER
}

Received: March 2, 2016-Accepted: April 15, 2016

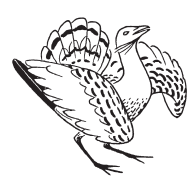

Gábor Ónodi \& Dániel Winkler 2016. Nest site characteristics of the Great-spotted Woodpecker in a bottomland riparian forest in the presence of invasive tree species. - Ornis Hungarica 24(1): 81-95. forest during the breeding seasons of 2014 and 2015. The occurrence of two invasive tree species, the green ash and boxelder, is significant in the study area, which influences negatively the populations of native riparian tree species in Central Europe. We studied Great-spotted Woodpecker nest sites in the presence of these invasive species. Throughout the study period, eight and twelve nesting cavity trees were mapped. Trees were recorded in 2020 circular plots of 0.05 ha both for each mapped nest trees and random plots as well. Species, diameter at breast height and condition were recorded for each tree. Composition and diversity of nest site and random plots were compared. Distributions and preferences were calculated for nest tree use. Most of the recorded trees were invasive. Nest site plots had more native trees compared to random plots. Nest site showed higher diversity in terms of all three variables. Decayed and dead willow and white poplar hybrid trees were preferred for nesting. Diameter at breast height of nest trees was between 30-90 cm. Studies about cavity excavators in transformed habitats have high importance for nature conservation of riparian forests.

Keywords: Picidae, breeding, alluvial forest, green ash, boxelder maple

Összefoglalás A vizsgálatot 2014-2015-ben, egy kezeletlen folyó-menti füz-nyár ártéri erdőben végeztük. A területen két inváziós fafaj fordul elö, az amerikai kőris és a zöld juhar. A két faj Közép-Európa szerte negatívan befolyásolja az ártéri erdőkben őshonos fafajok állományait. A nagy fakopáncs költőterületét vizsgáltuk az említett inváziós fafajok jelenlétében. A vizsgálati periódusban 8 , illetve 12 költőodút térképeztünk fel. A fás vegetációt 0,05 hektáros, kör alakú mintaterületeken mértük fel 20 költőhelyen, illetve 20 random mintaterületen. Rögzítettük a fák faját, mellmagassági átmérőjét, kondícióját. A költő- és random mintaterületek összetételét és diverzitását hasonlítottuk össze. Mind a költőhelyeken, mind a random mintaterületeken a legnagyobb arányban a két inváziós faj volt jelen, ám a költőterületeken gyakoribbak voltak az őshonos, és ritkábbak az inváziós fajok a random mintaterületekhez képest. A költőhelyeken az idősebb, korhadt, illetve holt fák nagyobb elegyarányban voltak jelen. A költőhelyek diverzitása mindhárom vegetációs változó esetében nagyobb volt. A vizsgált faj egyedei költőodúk készítésére a korhadó, valamint holt füz és szürke nyárfákat részesítették előnyben. Ezek mellmagassági törzsátmérője 30-90 cm-es között változott. Az odúkészítő fajokról szóló vizsgálatok az átalakult ártéri élöhelyeken nagy jelentőségủek a megfelelő természetvédelmi kezelések kidolgozásához.

Kulcsszavak: Picidae, költés, ártéri erdők, amerikai kőris, zöld juhar

Institute of Wildlife Management and Vertebrate Zoology, University of West Hungary, 9400 Sopron, Bajcsy-Zsilinszky utca 4.Hungary,e-mail: onodi.gabor@emk.nyme.hu,crocutathe1st@gmail.com *corresponding author 


\section{Introduction}

Riparian forests maintain high natural and conservational value. These forests provide source-rich habitats for a high diversity of species. Alluvial forests also serve as green corridors for forest associated species to maintain their opportunities for dispersing. These habitats are highly threatened by river control management and inter alia invasive plant species. Numerous European rivers were regulated for economic reasons and their river beds were transformed to more straight statuses. In lowland Central Europe, riparian forests have two main distinguished types: the willow-poplar forests (softwood gallery forests), situated closer to the river bed; and further away, the oak-ash-elm forests (hardwood gallery forests). Distribution of hardwood gallery forests has drastically decreased as a result of river control, dam management or forest clearing for agricultural land use. Most softwood gallery forests of Hungary are composed of poplar and willow species with dominant native species like white poplar (Populus alba), black poplar (Populus nigra), white willow (Salix alba) and crack willow (Salix fragilis). Because of their high genetic similarity, the Hungarian distribution of aspen (Populus tremula) and white poplar overlap; thus, hybrids with high variability and introgressive populations of poplars are present in the riparian forests. Due to the extensive distribution of planted hybrid poplar $(P . \times$ euramericana), nowadays the majority of trees that resemble black poplar in these forests are most likely hybrids of black poplar and the planted Euamerican poplars (Haraszthy 2001, Gencsi \& Vancsura 2002).

Floodplain forests are especially at risk of alien plant invasion because of the permanent propagulum supply and the presence of moist, nutrient-rich disturbed habitats which are very suitable for new establishment. Among the invasive tree species the green ash (Fraxinus pennsylvanica) and boxelder (Acer negundo) are the most notable mainly in the underand midstorey level. Due to their abundant and effective dispersed fruits, rapid growth and good regenerative capacities, they have a strong transformative effect on the species composition of floodplain forests by hindering the renewal of native species, of which very few seedlings and saplings can be found in such forests. They influence the chemical traits of the soil and also develop a second canopy layer under the canopy of native trees and thus increasingly shade the ground preventing the saplings of the autochtonous trees from growing properly (Csiszár \& Bartha 2008, Udvardy 2008, Erfmeier et al. 2011).

In North America, the green ash and the boxelder maple are considered to be mid-successional species as they live in an intermedier lane between the early-successional willow-poplar and the late-successional ash-elm riparian forests. Our focal species are present in the midstorey and the lower canopy layer of the two above-mentioned habitats. They tolerate the higher ground water levels and floods less and the droughts more than the willow and poplar species (Rumble \& Gobeille 1998). In addition to the above-mentioned habitat preferences of the two species, the river control managements happened to be beneficial for the green ash and the boxelder maple as the floods are scarcer and the level of ground water is deeper. These species survive more successfully in the shade and grow better at the clearings of the source-rich European riparian forests, than the European willow and poplar species (Saccone et al. 2010, Porté et al. 2011). These species also produce allelopathic chemicals that can prevent the saplings of native species from developing properly (Csiszár 2009, Csiszár et al. 2013). As a result, there 
are very few saplings of the native species in the study area, making these habitats more homogenous than one and a half century ago. Nowadays, aging poplar and willow trees and various generations of these two invasive species can be found simultaneously in these forests. This is a widespread environmental problem in the bottomland riparian forests of Central Europe (Mihály \& Botta-Dukát 2004, Erfmeier et al. 2011).

Picid birds (Picidae) can be considered as keystone species playing key role in forest ecosystems (Gorman 2011). A total of 277 species are known worldwide, while only 11 species are native to Europe (9 of them are breeding in Hungary) (Lammertink 2014). These species live in woody habitats and feed mainly on arthropods. Cavity-excavator species can only breed in habitats where trees are old and thick enough to allow for the production of cavities within them (Gorman 2004). A high number of animal species depend on tree cavities. Among others, cavity-excavators can provide nesting opportunities for other cavity-dwelling species. Cavity-nester birds include ducks (Anatidae), owls (Strigidae), doves (Columbidae), flycatchers (Muscicapidae) and tits (Paridae) etc., while the most frequent mammalian cavity-dweller species are rodents (Rodentia) and bats (Chiroptera) (Bai et al. 2005, Politi et al. 2010). Apart from vertebrates, we can also find several examples for secondary cavity-dwelling invertebrates including wasps (Hymenoptera) or butterflies (Lepidoptera).To maintain the diversity of cavity-dwellers, it is essential to protect the cavity-excavators as well. Woodpeckers can be considered as umbrella species since through their protection it is possible to protect other species. Each woodpecker species has distinct habitat preferences in terms of both foraging and nesting. Habitat utilization studies of cavity excavator species can support the conservation of their secondary cavity-dweller species as well (Ross et al. 1997, Mazgajski 1998, Martin \& Eadie 1999, Adkins Giese \& Cuthbert 2003, Melletti \& Penteriani 2003, Kosiński \& Winiecki 2004, Martin et al. 2004, Kosiński et al. 2006, Pasinelli 2007, Roberge et al. 2008a, 2008b, Vaillancourt et al. 2008, Wan et al. 2008, Hebda 2009, Kozma 2009, Edman et al. 2011, Gorman 2011, Cooke \& Hannon 2012).

Numerous works have examined the nest site use of certain woodpecker species (Mazgajski 1998, Kosiński \& Winiecki 2004, Pasinelli 2007, Hebda 2009, Kozma 2009). Nevertheless, one can barely find any such studies that took place in habitats highly transformed by invasive plant species. There is an increasing need for such studies, as there are altered habitats worldwide with actual range expansion. According to climate change scenarios, habitat transformations will spread around the globe (Starzomski 2013).

There is a huge lack of knowledge about the mentioned, altered riparian habitats, though this environmental problem is considered to be widespread in Central Europe. Beyond the changes in vegetation characteristics, the fauna and so the cavity-nesting communities happened to be affected by this problem. The Great-spotted Woodpecker (Dendrocopos major) is the most common woodpecker species in Europe, being present with high densities in most woody habitats, thus making the most cavities. As a generalist species could have a crucial role in such altered communities as the main cavity-excavating species. For further understanding, it is important to study the habitat use of this species in such transformed habitats (Ónodi \& Csörgő 2013, 2014).

The questions of our study were the following: Are there any compositional differences between the characteristics of nest site and random plots? What detailed characteristics do nest trees have? 


\section{Material and methods}

Our study area was a 60-70-year old unmanaged riparian poplar-willow forest (cc. 35 ha) (N $47^{\circ} 04^{\prime}$ E $20^{\circ} 11^{\prime}-\mathrm{N} 47^{\circ} 02^{\prime}$ E $20^{\circ} 11^{\prime}$ ) situated in the Central-Tisza Landscape Protection Area, which belongs to the Hortobágy National Park, in the floodplain area of the river Tisza (Figure 1). The following native tree species were recorded: white poplar, black poplar, white willow, crack willow. Among the overstorey species, there are some introduced tree species in the area: green ash, boxelder maple, white mulberry (Morus alba) and common hackberry (Celtis occidentalis). Among them, the green ash and the boxelder maple are known to be invasive plants as well. The midstorey consisted mainly of the saplings of the above mentioned invasive species. The other scrub layer species are European dewberry (Rubus caesius) and, at the edges, the North-American bastard indigobush (Amorpha fruticosa).

Apart from the study species, the Great-spotted Woodpecker, three other woodpecker species are breeding in lower densities in the area: the Lesser-spotted Woodpecker (Dryobates minor), the Green and the Black Woodpecker (Picus viridis and Dryocopus martius).

\section{Bird census}

Great-spotted Woodpecker nest trees were mapped in the breeding seasons of 2014 and 2015, as we followed the chirping begging calls of the nestlings (Kosiński \& Winiecki 2004, Kosiński et al. 2006, Pasinelli 2007). 8 and 12 cavity trees were mapped, respectively. None of the nest trees of the latter year were reused from the former year.

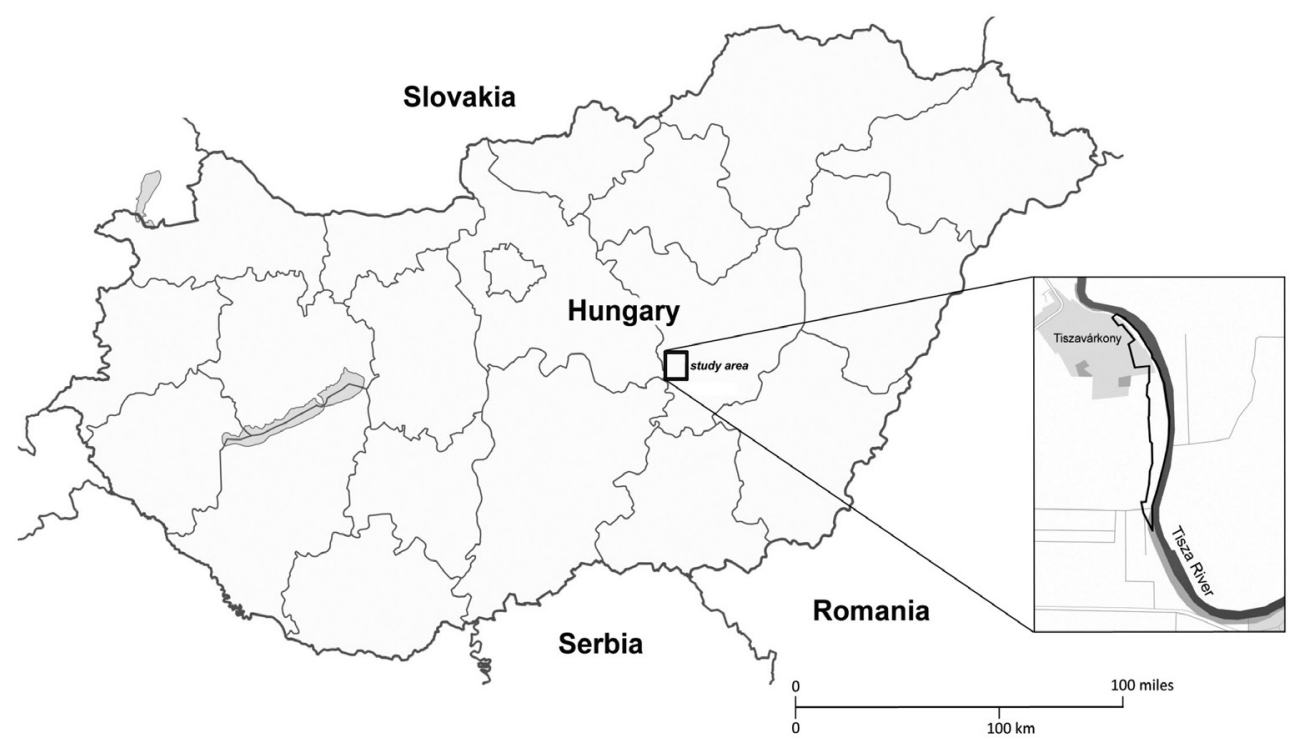

Figure 1. Map of the study area (N47연 $\left.4^{\prime} ; \mathrm{E} 20^{\circ} 11^{\prime}-\mathrm{N} 47^{\circ} 02^{\prime} ; \mathrm{E} 20^{\circ} 11^{\prime}\right)$

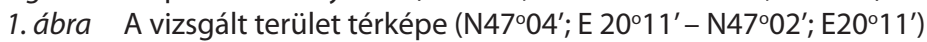




\section{Vegetation survey}

Characteristics of habitat were measured in $12.62 \mathrm{~m}$ radius circular plots $(0.05 \mathrm{ha})$ centred on 20 active woodpecker nest trees and on 20 points, randomly selected from 32 semi-random plots on a $100 \mathrm{~m}$ by $100 \mathrm{~m}$ grid. Tree species, DBH (diameter at breast height) and condition of each tree were recorded in every plot. Only trees with $\mathrm{DBH}$ greater than $3 \mathrm{~cm}$ were recorded, because this value is supposed to be the minimum diameter of trees that support prey species for the Great-spotted Woodpecker (Gorman 2004).

Tree species were recorded according to the following categories: willow species (W.), black poplar and its hybrids ( $\mathrm{Pb}$.), white poplar and its hybrids (Pw.), green ash (A.), boxelder maple (M.), white mulberry (Mb.) and common hackberry (H.). In parallel with the current study, we have been gathering data on foraging microhabitat use of the studied species all year round. So that, both willow species were listed in one single category due to the very similar architecture and bark structure which makes difficult to identify the exact species when the branches are covered with snow.

Vegetation parameters were recorded after earlier studies on woodpecker nest site utilization (Hogstad 1971, Pettersson 1983, Török \& Csorba 1986, Morrison \& With 1987, Török 1990, Aulén \& Lundberg 1991, Suhonen \& Kuitonen 1991, Engstrom \& Sanders 1997, Osiejuk 1998, Imbeau \& Desrochers 2002, Pechacek 2006, Hogstad 2009, Czeszczewik 2010). Diameter at breast height was recorded in $10 \mathrm{~cm}$ intervals. The category for the thickest trees was "> $>100 \mathrm{~cm}$ ". Condition of trees was assigned in three categories: living trees (less than half of their branches are decayed), decaying trees (more than half of their branches are decayed, but still have living branches) and dead trees (the whole tree and all of the branches are dead). The thickness of the utilized part of tree was assigned to one of the following six categories: $<10.1 \mathrm{~cm}, 10.1-20 \mathrm{~cm}, 20.1-30 \mathrm{~cm}, 30.1-40 \mathrm{~cm}, 40.1-50 \mathrm{~cm}$, $50 \mathrm{~cm}<$. We estimated the thickness of the branch relative to the biometric measures of the study species (length 21-23 cm, wingspan 34-39 cm) (Cramp 1985). We gathered data on the condition of the used substrate in three categories: "Living", "Decaying" and "Dead".

\section{Data analyses}

Chi-square test was used to compare the distributions in species, DBH and condition between nest site and random plots.

Shannon diversity index was calculated for tree species, DBH and condition in the case of each plot. Diversity indices of nest site and random plots were compared through Hutcheson's diversity t-test (Hutcheson 1970, Poole 1974).

The ratio of the number of native trees to the pooled number of native and invasive trees was calculated for each plot. Values of nest site and random plots were compared with two-sample t-test with Welch correction.

According to the availability of each category of the three dimensions measured at random plots, frequency distributions and Jacobs' selectivity indices were calculated to examine which type of trees were used and preferred for nesting cavity excavation. This index can result in values from -1 to +1 , where negative values are referring to avoidance 


\begin{tabular}{|l|r|r|}
\hline \multicolumn{1}{|c|}{ Tree species } & $\begin{array}{c}\text { Nest site } \\
(\mathbf{6 8 0 )}\end{array}$ & $\begin{array}{c}\text { Random } \\
\text { (566) }\end{array}$ \\
\hline Willow & $17.79 \%$ & $9.01 \%$ \\
\hline White poplar hybrid & $13.09 \%$ & $10.78 \%$ \\
\hline Black poplar hybrid & $9.85 \%$ & $3.89 \%$ \\
\hline Green ash & $24.71 \%$ & $29.86 \%$ \\
\hline Boxelder maple & $28.68 \%$ & $41.87 \%$ \\
\hline White mulberry & $5.29 \%$ & $3.89 \%$ \\
\hline Common hackberry & $0.59 \%$ & $0.71 \%$ \\
\hline
\end{tabular}

Table 1. Frequency distributions of tree species in the nest site and random plots

1. táblázat Az egyes fafajok gyakoriság-eloszlásai a költőhelyen, illetve random plotokban. Fafajok fentről lefelé: fűz, fehér nyár hibridek, fekete nyár hibridek, amerikai kőris, zöld juhar, fehér eper, nyugati ostorfa

and positive values are referring to preference. For these measures, we only worked with trees of a DBH greater than $10 \mathrm{~cm}$.

Analyses were carried out with PAST 2.17c (Hammer et al. 2001). Tables were managed with Microsoft Office Excel 2007 software.

\section{Results}

The most frequent tree species were the invasive species, among them the most abundant is the boxelder maple, while native tree species were less abundant. At the random

\begin{tabular}{|c|c|c|}
\hline $\begin{array}{c}\text { Tree diameter at } \\
\text { breast height }\end{array}$ & $\begin{array}{c}\text { Nest site } \\
\mathbf{( 6 8 0 )}\end{array}$ & $\begin{array}{c}\text { Random } \\
\mathbf{( 5 6 6 )}\end{array}$ \\
\hline $3.1-10 \mathrm{~cm}$ & $32.35 \%$ & $45.41 \%$ \\
\hline $10.1-20 \mathrm{~cm}$ & $23.82 \%$ & $21.73 \%$ \\
\hline $20.1-30 \mathrm{~cm}$ & $14.26 \%$ & $13.78 \%$ \\
\hline $30.1-40 \mathrm{~cm}$ & $8.97 \%$ & $5.48 \%$ \\
\hline $40.1-50 \mathrm{~cm}$ & $6.91 \%$ & $4.95 \%$ \\
\hline $50.1-60 \mathrm{~cm}$ & $3.97 \%$ & $2.65 \%$ \\
\hline $60.1-70 \mathrm{~cm}$ & $3.38 \%$ & $1.59 \%$ \\
\hline $70.1-80 \mathrm{~cm}$ & $2.06 \%$ & $2.30 \%$ \\
\hline $80.1-90 \mathrm{~cm}$ & $1.47 \%$ & $0.88 \%$ \\
\hline $90.1-100 \mathrm{~cm}$ & $1.32 \%$ & $0.53 \%$ \\
\hline $100 \mathrm{~cm}<$ & $1.47 \%$ & $0.71 \%$ \\
\hline
\end{tabular}

Table 2. Frequency distributions of tree diameter at breast height in the nest site and random plots

2. táblázat $\mathrm{Az}$ egyes mellmagasságban mért törzsátmérő kategóriák gyakoriság-eloszlásai a költőhelyen, illetve random plotokban

\begin{tabular}{|l|c|c|}
\hline \multicolumn{1}{|c|}{ Tree condition } & $\begin{array}{c}\text { Nest site } \\
(\mathbf{6 8 0 )}\end{array}$ & $\begin{array}{c}\text { Random } \\
\text { (566) }\end{array}$ \\
\hline Living & $30.88 \%$ & $39.93 \%$ \\
\hline Decaying & $58.24 \%$ & $53.71 \%$ \\
\hline Dead & $10.88 \%$ & $6.36 \%$ \\
\hline
\end{tabular}

Table 3. Frequency distributions of tree condition in the nest site and random plots

3. táblázat Az egyes fakondíció kategóriák gyakoriság eloszlásai a költőhelyen, illetve random plotokban (kondíció kategóriák fentről lefelé: élő, korhadó, holt) plots, white poplar hybrids were the most abundant native trees, while willow trees were the most frequent in the nest site plots. White mulberry and common hackberry trees happened to be sporadic species. Nest site plots had less invasive trees and more native trees than random plots (Table 1). $\mathrm{Chi}^{2}$ test showed significant difference between the two distributions $\left(\mathrm{X}^{2}=53.955, \mathrm{df}=6, \mathrm{P}<0.0001\right)$.

Both plot types had gradually less trees in the greater DBH categories, although thinner, younger trees were represented in lower proportions in the nest sites (Table 2). Chi ${ }^{2}$ test showed significant difference between the two distributions $\left(\mathrm{X}^{2}=29.885, \mathrm{df}=9, \mathrm{P}<0.0001\right)$.

Decaying trees were represented the most and dead trees the least at both types of plots, although nest site plots had more decaying and dead trees and less living trees (Table 3). 


\begin{tabular}{|c|c|c|}
\hline Plot & Nest site (680) & Random (566) \\
\hline 1 & 1.18 & 1.16 \\
\hline 2 & 1.46 & 1.18 \\
\hline 3 & 1.54 & 0.91 \\
\hline 4 & 0.88 & 0.44 \\
\hline 5 & 1.09 & 1.10 \\
\hline 6 & 1.59 & 1.29 \\
\hline 7 & 1.03 & 1.08 \\
\hline 8 & 1.45 & 1.41 \\
\hline 9 & 1.36 & 1.04 \\
\hline 10 & 1.20 & 1.44 \\
\hline 11 & 1.34 & 1.15 \\
\hline 12 & 1.11 & 1.17 \\
\hline 13 & 1.22 & 1.15 \\
\hline 14 & 1.26 & 1.47 \\
\hline 15 & 1.37 & 1.42 \\
\hline 16 & 0.85 & 1.24 \\
\hline 17 & 1.16 & 1.45 \\
\hline 18 & 1.43 & 1.08 \\
\hline 19 & 1.24 & 1.03 \\
\hline 20 & 1.45 & 1.23 \\
\hline Mean & 1.26 & 1.17 \\
\hline SD & 0.20 & 0.23 \\
\hline
\end{tabular}

Table 4. Tree species diversity (Shannon) in the nest site and random plots

4. táblázat Shannon diverzitási értékek a fafajok esetében a költőhelyen, illetve random plotokban

\begin{tabular}{|r|c|c|}
\hline Plot & Nest site (680) & Random (566) \\
\hline 1 & 27.98 & 81.87 \\
\hline 2 & 138.30 & 108.73 \\
\hline 3 & 76.79 & 50.75 \\
\hline 4 & 55.51 & 122.25 \\
\hline 5 & 38.55 & 135.69 \\
\hline 6 & 95.09 & 36.75 \\
\hline 7 & 139.54 & 58.83 \\
\hline 8 & 38.85 & 72.58 \\
\hline 9 & 89.55 & 26.32 \\
\hline 10 & 18.30 & 59.42 \\
\hline 11 & 25.98 & 2.77 \\
\hline 12 & 65.28 & 41.87 \\
\hline 13 & 84.82 & 41.82 \\
\hline 14 & 96.59 & 8.32 \\
\hline 15 & 37.20 & 24.46 \\
\hline 16 & 78.66 & 88.60 \\
\hline 17 & 67.85 & 82.99 \\
\hline 18 & 49.14 & 52.85 \\
\hline 19 & 68.93 & 49.99 \\
\hline 20 & 26.86 & 41.39 \\
\hline Mean & 65.99 & 59.41 \\
\hline SD & 34.93 & 35.60 \\
\hline & & \\
\hline
\end{tabular}

Table 5. Shannon diversity indices in the case of tree diameter at breast height in the nest site and random plots

5. táblázat Shannon diverzitási értékek mellmagasságban mért törzsátmérő esetében a költőhelyen, illetve random plotokban

$\mathrm{Chi}^{2}$ test showed significant difference between the two distributions $\left(\mathrm{X}^{2}=15.505, \mathrm{df}=2\right.$, $\mathrm{P}<0.0001$ ).

Nest site plots showed higher diversity values in the case of tree species (Table 4), diameter at breast height (Table 5) and tree condition (Table 6). Diversity t-test showed significant differences between nest site and random plots in terms of Shannon diversity indices of tree species $(\mathrm{t}=5.607, \mathrm{df}=953.43, \mathrm{P}<0.0001)$ and diameter at breast height $(\mathrm{t}=4.8318, \mathrm{df}=1116$, $\mathrm{P}<0.0001)$. The $\mathrm{t}$-test did not show significant differences for tree condition $(\mathrm{t}=1.4687$, $\mathrm{df}=1223.7, \mathrm{P}=0.14218$ ).

According to the two-sample t-test with Welch correction, nest site plots had significantly higher values for ratio of the number of native trees to the pooled number of native and invasive trees, compared to the random plots (Table 7$) \mathrm{t}($ Welch $)=3.5591, \mathrm{p}($ Welch $\mathrm{t})=0.0014)$. 


\begin{tabular}{|r|c|c|}
\hline Plot & Nest site (680) & Random (566) \\
\hline 1 & 41.28 & 97.72 \\
\hline 2 & 179.59 & 123.18 \\
\hline 3 & 121.67 & 56.42 \\
\hline 4 & 85.11 & 150.93 \\
\hline 5 & 63.16 & 164.61 \\
\hline 6 & 118.83 & 38.03 \\
\hline 7 & 165.95 & 82.90 \\
\hline 8 & 54.21 & 96.39 \\
\hline 9 & 123.48 & 36.95 \\
\hline 10 & 33.34 & 72.58 \\
\hline 11 & 48.04 & 6.59 \\
\hline 12 & 103.83 & 56.37 \\
\hline 13 & 97.02 & 63.93 \\
\hline 14 & 137.23 & 26.38 \\
\hline 15 & 53.58 & 30.26 \\
\hline 16 & 115.89 & 119.46 \\
\hline 17 & 95.07 & 115.84 \\
\hline 18 & 85.11 & 52.51 \\
\hline 19 & 93.81 & 81.82 \\
\hline 20 & 44.40 & 61.30 \\
\hline Mean & 93.03 & 76.71 \\
\hline SD & 41.39 & 42.40 \\
\hline
\end{tabular}

Table 6. Shannon diversity indices in the case of tree condition in the nest site and random plots

6. táblázat Shannon diverzitási értékek a fakondíció esetében a költőhelyen, illetve random plotokban

\begin{tabular}{|c|c|c|}
\hline Plot & Nest site (680) & Random (566) \\
\hline 1 & 0.65 & 0.39 \\
\hline 2 & 0.38 & 0.21 \\
\hline 3 & 0.46 & 0.08 \\
\hline 4 & 0.56 & 0.16 \\
\hline 5 & 0.92 & 0.18 \\
\hline 6 & 0.39 & 0.18 \\
\hline 7 & 0.12 & 0.35 \\
\hline 8 & 0.27 & 0.30 \\
\hline 9 & 0.42 & 0.20 \\
\hline 10 & 0.15 & 0.19 \\
\hline 11 & 0.33 & 0.29 \\
\hline 12 & 0.38 & 0.38 \\
\hline 13 & 0.27 & 0.32 \\
\hline 14 & 0.53 & 0.38 \\
\hline 15 & 0.39 & 0.21 \\
\hline 16 & 0.92 & 0.24 \\
\hline 17 & 0.37 & 0.35 \\
\hline 18 & 0.45 & 0.13 \\
\hline 19 & 0.33 & 0.36 \\
\hline 20 & 0.35 & 0.14 \\
\hline Mean & 0.43 & 0.25 \\
\hline SD & 0.21 & 0.10 \\
\hline & & \\
\hline
\end{tabular}

Table 7. Ratio values for the number of native trees to the sum of the number of native and invasive trees in the nest site and random plots

7. táblázat Őshonos fák aránya az őshonos és inváziós fák összegéhez képest a költőhelyen, illetve random plotokban

12 nests out of 20 were made in willow trees, 7 nests were made in white poplar hybrids and one nest was made in a boxelder maple tree, which means $60 \%, 35 \%$ and $5 \%$, respectively. According to Jacobs' selectivity indices, birds showed preference for willows and white poplar hybrids. The highest preference value was observed for willow trees. All other trees were avoided by the studied species, but boxelder maple showed slightly lower avoidance (Table 8).

For cavity excavation, a wide range of $\mathrm{DBH}$ was utilized from trees between 10.1 and $20 \mathrm{~cm}$ to trees of maximum $90 \mathrm{~cm}$ thickness. Most of the nest trees were between 30.1 and $50 \mathrm{~cm}$ thick. According to their availability, the preferred trees were ranged from 30.1 to $70 \mathrm{~cm}$, but $80.1-90 \mathrm{~cm} \mathrm{DBH}$ trees were also preferred. Other categories were avoided (Table 9). 


\begin{tabular}{|l|c|c|}
\hline \multicolumn{1}{|c|}{ Tree species } & $\begin{array}{c}\text { Utilization } \\
\text { frequen- } \\
\text { cies }\end{array}$ & $\begin{array}{c}\text { Jacobs' } \\
\text { selectivity } \\
\text { indices }\end{array}$ \\
\hline Willow & $60 \%$ & 0.77 \\
\hline White poplar hybrid & $35 \%$ & 0.38 \\
\hline Black poplar hybrid & $0 \%$ & -1.00 \\
\hline Green ash & $0 \%$ & -1.00 \\
\hline Boxelder maple & $5 \%$ & -0.81 \\
\hline White mulberry & $0 \%$ & -1.00 \\
\hline Common hackberry & $0 \%$ & -1.00 \\
\hline
\end{tabular}

Table 8. Utilization frequencies and Jacobs' selectivity indices for species of nest trees

8. táblázat Az egyes fafajok gyakoriság-eloszlásai és ezek Jacobs szelektivitási index értékei a költőfák esetében. Fafajok fentről lefelé: füz, fehér nyár hibridek, fekete nyár hibridek, amerikai kőris, zöld juhar, fehér eper, nyugati ostorfa

\begin{tabular}{|l|c|c|}
\hline Tree condition & $\begin{array}{c}\text { Utilization } \\
\text { frequencies }\end{array}$ & $\begin{array}{c}\text { Jacobs' } \\
\text { selectivity } \\
\text { indices }\end{array}$ \\
\hline Living & $10 \%$ & -0.55 \\
\hline Decaying & $75 \%$ & 0.28 \\
\hline Dead & $15 \%$ & 0.24 \\
\hline
\end{tabular}

Table 10. Utilization frequencies and Jacobs' selectivity indices for condition of nest trees

10. táblázat Az egyes fakondíció kategóriák gyakoriság-eloszlásai és ezek Jacobs szelektivitási index értékei a költőfák esetében (kondíció kategóriák fentről lefelé: élő, korhadó, holt)

\begin{tabular}{|l|c|}
\hline \multicolumn{1}{|c|}{ Substrate condition } & $\begin{array}{c}\text { Utilization } \\
\text { frequencies }\end{array}$ \\
\hline Living & $10 \%$ \\
\hline Decaying & $75 \%$ \\
\hline Dead & $15 \%$ \\
\hline
\end{tabular}

Table 12. Frequency distributions of substrate condition at nesting cavities

12. táblázat Az egyes fakondíció kategóriák gyakoriság-eloszlásai a költőodúknál (kondíció kategóriák fentről lefelé: élő, korhadó, holt)

\begin{tabular}{|c|c|c|}
\hline $\begin{array}{c}\text { Tree diameter at } \\
\text { breast height }\end{array}$ & $\begin{array}{c}\text { Utilization } \\
\text { frequen- } \\
\text { cies }\end{array}$ & $\begin{array}{c}\text { Jacobs' } \\
\text { selectivity } \\
\text { indices }\end{array}$ \\
\hline $10.1-20 \mathrm{~cm}$ & $0 \%$ & -1.00 \\
\hline $20.1-30 \mathrm{~cm}$ & $10 \%$ & -0.50 \\
\hline $30.1-40 \mathrm{~cm}$ & $35 \%$ & 0.66 \\
\hline $40.1-50 \mathrm{~cm}$ & $25 \%$ & 0.54 \\
\hline $50.1-60 \mathrm{~cm}$ & $10 \%$ & 0.37 \\
\hline $60.1-70 \mathrm{~cm}$ & $15 \%$ & 0.71 \\
\hline $70.1-80 \mathrm{~cm}$ & $0 \%$ & -1.00 \\
\hline $80.1-90 \mathrm{~cm}$ & $5 \%$ & 0.52 \\
\hline $90.1-100 \mathrm{~cm}$ & $0 \%$ & -1.00 \\
\hline $100 \mathrm{~cm}<$ & $0 \%$ & -1.00 \\
\hline \multicolumn{2}{|c|}{} \\
\hline
\end{tabular}

Table 9. Utilization frequencies and Jacobs' selectivity indices for diameter at breast height of nest trees

9. táblázat $\mathrm{Az}$ egyes mellmagasságban mért törzsvastagság kategóriák gyakoriság-eloszlásai és ezek Jacobs szelektivitási index értékei a költőfák esetében

\begin{tabular}{|c|c|}
\hline $\begin{array}{c}\text { Diameter at nest } \\
\text { height }\end{array}$ & $\begin{array}{c}\text { Utilization } \\
\text { frequencies }\end{array}$ \\
\hline $0-10 \mathrm{~cm}$ & $0 \%$ \\
\hline $10.1-20 \mathrm{~cm}$ & $5 \%$ \\
\hline $20.1-30 \mathrm{~cm}$ & $60 \%$ \\
\hline $30.1-40 \mathrm{~cm}$ & $25 \%$ \\
\hline $40.1-50 \mathrm{~cm}$ & $5 \%$ \\
\hline $50 \mathrm{~cm}<$ & $5 \%$ \\
\hline
\end{tabular}

Table 11. Frequency distributions of tree diameter at nest height

11. táblázat $\mathrm{Az}$ egyes költőodúknál becsült törzsvastagság kategóriák gyakoriság-eloszlásai 
$75 \%$ of nest trees were in "decaying" condition. $15 \%$ of the utilized trees were dead and $10 \%$ were living. The preferred condition stages were the "decaying" and the "dead", where decaying trees were more preferred. Living trees were avoided (Table 10).

$60 \%$ of nesting cavities were excavated in parts of trees with the diameter at nest height of 20.1-30 cm. Other categories were represented less and less (Table 11). 75\% of nesting cavities were excavated in decaying substrates (Table 12).

\section{Discussion}

Within the literature one can rarely find studies on nest site use of the Great-spotted Woodpecker in riparian forests. These studies were carried out mostly in oak-ash-elm forests (Fraxino-Ulmetum) (Kosiński \& Winiecki 2004, Kosiński et al. 2006), while none of them took place in willow-poplar alluvial forests (Populo-Salicetum). Besides, we could not find any example of woodpecker nest site studies in habitats transformed by invasive tree species. There is a huge lack of knowledge on these topics so far.

Among native trees, nest site plots had more trees from all of the available three species, but the difference was proportionately bigger in terms of willow and black poplar hybrid trees, than white poplar hybrids. In one of our earlier studies made in the same study area, through weekly standard, year-round foraging observations, we found, that invasive tree species were avoided (Ónodi \& Csörgő 2014). In spite of that, among other tree species, the rough barked native willow and black poplar hybrids were the most preferred trees for foraging (Ónodi \& Csörgő 2014). The green ash and boxelder maple were scarcely used for foraging by the study species (Ónodi \& Csörgö 2014). This could be due to that these tree species have very few prey items in them. Both non-native species have anti-herbivore secondary metabolic products in their tissues, in the leaves and in the living wood as well (Csiszár \& Bartha 2008, Udvardy 2008, Csiszár 2009). Among the few insect species that can inhabit the wood of green ash, the most common is the Ash Bark Beetle (Leperisinus fraxini, Scolytidae) that lives in the bark of the trees (Udvardy 2008). According to the literature, there is not any documented wood boring insect species, which could inhabit the wood of boxelder in Europe (Csiszár \& Bartha 2008).

Foraging woodpeckers preferred bigger, older native trees, which could be the reason why nest site plots had more abundant thicker, older trees and less young trees than random plots. This phenomenon is similar to the results of Kosinski and Winiecki (2004). They found in Quercus-Fraxinus-Ulmus and Quercus-Carpinus stands in Poland, that Great-spotted Woodpeckers used nest sites with proportionately bigger and older trees of higher total basal area.

Most trees were decaying at both nest site and random plots. Nest site plots had more decaying and dead trees and less living trees. Although living trees were preferred by the foraging birds, nest site plots had proportionately less living trees than random plots. This could be from the fact that most of the living trees in the study area are invasive and thus avoided by the foraging birds for both foraging and nesting (Ónodi \& Csörgö 2014).

According to our results, nest site plots had higher diversity in terms of all three studied variables, as birds chose nest sites with more thick, decaying or dead native trees, while the 
overall characteristics of this transformed habitat are less diverse, due to the high frequencies of young, living invasive trees.

As there are so few studies on the nest site utilizations of the Great-spotted Woodpecker and we could not find any studies held in poplar-willow riparian forests so far, it is hard to compare their nest tree utilizations as well. In other studies, willow trees were not among the preferred nest trees, although these trees were sporadically present in those study sites (Kosiński \& Winiecki 2004, Kosiński et al. 2006). Willow trees were only mentioned by Kosiński et al. (2006) as highly preferred nest tree species for the Middle-spotted Woodpeckers. In our study area, these tree species provide the most suitable, $20-30 \mathrm{~cm}$ thick substrates with the proper volume of soft decaying wood. As white poplar hybrid trees are hybrids of white poplar and aspen trees, our studied woodpeckers used these trees similarly to Aspens that were used in other studies as well. Aspens were preferred by Great-spotted Woodpeckers for example in Bialowieza National Park in Poland (Wesolowski \& Tomialojc 1986), in Norway (Hagvar et al. 1990) and in Sweden (Hansson 1992). The used aspen cavity trees were described as dead and decaying trees in case of Bialowieza, but were considered to be living trees in both the Norwegian and Swedish studies. Such high preference could be related to its soft wood, which can mean less effort for excavation (Kosiński \& Kempa 2007). The other preferred trait of this species is its smooth bark. The latter trait could lower the success of scansorial nest predators such as Pine Marten (Martes martes) and Stone Marten (M. foina) (Glue \& Boswell 1994, Walankiewicz \& Czeszczewik 2005).

Great-spotted Woodpecker chose dead and decaying trees for nesting in other studies as well (Glue \& Boswell 1994, Smith 1995, Smith 1997, Kosiński \& Winiecki 2004, Smith 2007), although, among other European woodpecker species, the Great-spotted Woodpecker use living trees the most. In some studies the species used near exclusively living trees for nesting (Kosiński \& Kempa 2007). Compared to other Dendrocopos species, like the dead wood specialist White-backed Woodpecker (D. leucotos) which has a slightly greater body size and considerably greater bill length (Gorman 2004), the Great-spotted Woodpecker's shorter and deeper bill occurred to be more efficient for excavating nesting cavities in hard, living trees (Aulén \& Lundberg 1991). According to the condition of such transforming riparian habitats, high proportion of native trees suitable for nesting are in decaying or dead condition as well. Older willow and white poplar hybrid trees are mostly decaying under these soil water conditions. In contrary to other studies in which cavities were found in old, larger trees with 50-60 cm diameter at breast height (Kosiński \& Winiecki 2004), our study birds mainly excavated their nesting cavities in medium diameter trees of 30-40 $\mathrm{cm}$. These trees represented $10 \%$ of the available stems applicable for cavity excavation by Great-spotted Woodpecker. Equivocally with other studies, our studied species made cavities in substrates between 20 and $30 \mathrm{~cm}$ diameter at nest height (Glue \& Boswell 1994).

In their native habitats, in particularly in green ash woodlands, green ash and boxelder maple support a high diversity of forest bird species, including cavity-nesting species (Rumble \& Gobeille 2008). According to our results, we predict that the population decrease of native, alluvial tree species could lead to a suboptimal habitat for numerous members of riparian forest communities (Magura et al. 2008). In that case, the density of woodpecker 
species could decrease. As the main cavity excavator, the Great-spotted Woodpecker plays a key role in riparian forest ecosystems. Its decrease in density caused by habitat alteration would supposedly have a considerable influence on the cavity-dwelling community. Among the secondary cavity-nesters of this species we can find tits (Paridae), nuthatches (Sittidae), sparrows (Passeridae), starlings (Sturnidae) and flycathcers (Muscicapidae) (Kotaka \& Matsuoka 2002), even though the Great-spotted Woodpecker is one of the most important nest predators for cavity-nesting species, for example in the Bialowieza National Park, where certain species even avoid nesting in woodpecker cavities (Wesolowski 2007). Decaying processes of natural cavities could be initiated by the foraging excavations of woodpeckers, as they can inoculate wood-decaying fungi. Such holes, within decades can become nesting cavities. The wood of the invasive tree species is much harder, so these trees can produce hollows slower than willow and poplar trees; thereby, the importance of nesting and foraging cavities made by the generalist Great-spotted Woodpecker will undoubtedly rise (Jackson \& Jackson 2004).

Through their above mentioned processes, green ash and boxelder maple are considered to be such transforming species. In the making of conservation management plans, it is adequate to use the "novel ecosystem" approach. Certain transforming species can change fairly entire ecosystems in irreversible ways. The restoration of such habitats could be impossible or so resource intensive, that it could even cause great harm to the processes of the ecosystem. In our case, these invasive tree species support the essential midstorey and secondary canopy layer as important microhabitats for various forest-dwelling species. Managers should secure the current processes of such altered ecosystems while taking efforts to conserve the indigenous habitat as much as possible (Milton 2003, Hobbs et al. 2006, Lindenmayer et al. 2008, Hobbs et al. 2013).

As the green ash and boxelder maple are considered to be mid-successional species in their North-American, native alluvial habitats (Iverson et al. 2008, 2009), through river control managements the more straight, deeper riverbeds of Central Europe happened to be more optimal for these species, than the native riparian tree species. The conditions of native riparian woodland ecosystems could be mitigated by the restoration of natural, meandering and flooding processes of such riverbeds (Scott et al. 1997, van Turnhout et al. 2010), though this consideration is yet to be an utopistic approach due to inter alia economic reasons.

\section{Acknowledgements}

We would like to express our gratitude to the directorate of the Hortobágyi National Park, for giving permission for our field work, also to Béla Tallósi, ranger of the study area and to Ágnes Csiszár, who added botanical recommendations for our manuscript and to Tibor Hartel as well, who first mentioned the 'novel ecosystem' approach to the first author. Last, but not least, we would like to express our gratitude for the hard work of the two reviewers of the manuscript. 


\section{References}

Adkins Giese, C. L. \& Cuthbert, F. J. 2003. Influence of surrounding vegetation on woodpecker nest tree selection in oak forests of the Upper Midwest, USA. - Forest Ecology and Management 179: 523-534. DOI: 10.1016/S0378-1127(02)00529-7

Aulén, G. \& Lundberg, A. 1991. Sexual dimorphism and patterns of territory use by the White-backed Woodpecker Dendrocopos leucotos. - Ornis Scandinavica 22(1): 60-64. DOI: 10.2307/3676622

Bai, M-L., Wichmann, F. \& Mühlenberg, M. 2005. Nest-site characteristics of hole-nesting birds in a primeval boreal forest of Mongolia. - Acta Ornithologica 40(1): 1-14. DOI: 10.3161/068.040.0105

Cooke, H. A. \& Hannon, S. J. 2012. Nest-site selection by old boreal forest cavity excavators as a basis for structural retention guidelines in spatially-aggregated harvests. - Forest Ecology and Management 269: 37-51. DOI: 10.1016/j.foreco.2011.12.042

Csiszár, Á. 2009. Allelopathic effects of invasive woody plant species in Hungary. - Acta Silvatica et Lignaria Hungarica 5: 9-17.

Csiszár, Á. \& Bartha, D. 2008. Green ash (Fraxinus pennsylvanica Marsh.). - In: Botta-Dukát, Z. \& Mihály, B. (eds.). The most important invasive plants in Hungary. - Institute of Ecology and Botany, Hungarian Academy of Sciences, Vácrátót, Hungary, pp. 161-166.

Csiszár, Á., Korda, M., Schmidt, D., Špor, D., Süle, I. P., Teleki, B., Tiborcz, V., Zagyvai, G. \& Bartha, D. 2013. Allelopathic potential of some invasive plant species occurring in Hungary. - Allelopathy Journal 31: 309-318.

Edman, T., Angelstam, P., Mikusinski, G., Roberge, J-M. \& Sikora, A. 2011. Spatial planning for biodiversity conservation: Assessment of forest landscapes' conservation value using umbrella species requirements in Poland. - Landscape Urban Planning 102(1): 16-23. DOI: 10.1016/j.landurbplan.2011.03.004

Erfmeier, A., Böhnke, M. \& Bruelheide, E. 2011. Secondary invasion of Acer negundo: the role of phenotypic responses versus local adaptation. - Biological Invasions 13: 1599-1614. DOI: 10.1007/ s10530-010-9917-2

Gencsi, L. \& Vancsura, R. 2002. Dendrológia [Dendrology]. - Mezőgazda Kiadó, Budapest (in Hungarian)

Glue, D. E. \& Boswell, T. 1994. Comparative nesting ecology of the three British breeding woodpeckers. - British Birds 87: 253-269.
Gorman, G. 2004. Woodpeckers of Europe. A study of the European Picidae. - Chalfont St. Peter: Bruce Coleman

Gorman, G. 2011. The Black Woodpecker. A monograph on Dryocopus martius. - Lynx Edicions, Barcelona

Hagvar, S., Hagvar, G. \& Monness, E. 1990. Nest site selection in Norwegian woodpeckers. - Holarctic Ecology 13: 156-165. DOI: 10.1111/j.16000587.1990.tb00602.x

Hansson, L. 1992. Requirements by the Great-spotted Woodpecker Dendrocopos major for a suburban life. - Ornis Svecica 2: 1-6.

Hammer, O., Harper, D. A. T. \& Ryan, P. D. 2001. PAST: Paleontological statistics software package for education and data analysis. - Palaeontologia Electronica 4(1): 9.

Haraszthy, L. 2001. The floodplain forests in Hungary. - In: Klimo, E. \& Hager, H. (eds.) The floodplain forests in Europe. Current situation and perspectives. - European Forest Institute Research Report 10. Brill, Leiden, pp. 17-24.

Hebda, G. 2009. Nesting sites of the Great-spotted Woodpecker Dendrocopos major L. in Poland: analysis of nest cards. - Polish Journal of Ecology 57(1): 149-158.

Hobbs, R. J., Arico, S., Aronson, J., Baron, J. S., Bridgewater, P., Cramer, V. A., Epstein, P. R., Ewel, J. J., Klink, C. A., Lugo, A. E., Norton, D., Ojima, D., Richardson, D. M., Sanderson, E. W., Valladares, F., Vilà, M., Zamora, R. \& Zobel, M. 2006. Novel ecosystems: theoretical and management aspects of the new ecological world order. Global Ecology and Biogeography 15: 1-7. DOI: 10.1111/j.1466-822x.2006.00212.x

Hobbs, R. J., Higgs, E. S. \& Hall, C. M. 2013. Defining novel ecosystems. - In: Hobbs, R. J., Higgs, E. S. \& Hall, C. M. (eds.) Novel ecosystems. Intervening in the new ecological world order. Wiley-Blackwell, Chichester, pp. 58-60.

Hutcheson, K. 1970. A test for comparing diversities based on the Shannon formula. - Journal of Theoretical Biology 29: 151-154.

Iverson, L., Prasad, A. \& Matthews, S. 2008. Modelling potential climate change impacts on the trees of the northeastern United States. - Mitigation and Adaptation Strategies for Global Change 13(5-6): 487-516.

Iverson, L., Prasad, A. Matthews, S. \& Peters, M. 2009. Potential changes in tree habitat for Illinois under climate change. - In: Taft, J. (ed.) Canaries in the Catbird Seat, Chapter 16. - Illinois Natural 
History Survey Special Publication 30, Champaign, Illinois, pp. 263-270.

Jackson, J. A. \& Jackson B. J. S. 2004. Ecological relationships between fungi and woodpecker cavity sites. - The Condor 106(1): 37-49. DOI: $10.1650 / 7483$

Kosiński, Z. \& Kempa, M. 2007. Density, distribution and nest-sites of woodpeckers Picidae, in a managed forest of western Poland. - Polish Journal of Ecology 55(3): 519-533.

Kosiński, Z. \& Winiecki, A. 2004. Nest-site selection and niche partitioning among the Great-spotted Woodpecker Dendrocopos major and Middlespotted Woodpecker Dendrocopos medius in riverine forest of Central Europe. - Ornis Fennica $81: 145-156$.

Kosiński, Z., Ksit, P. \& Winiecki, A. 2006. Nest sites of Great-spotted Woodpeckers Dendrocopos major and Middle-spotted Woodpeckers Dendrocopos medius in near-natural and managed riverine forests. - Acta Ornithologica 41(1): 21-32. DOI: 10.3161/068.041.0108

Kotaka, N. \& Matsuoka, S. 2002. Secondary users of Great-spotted Woodpecker (Dendrocopos major) nest cavities in urban and suburban forests in Sapporo City, northern Japan. - Ornithological Science 1(2): 117-122. DOI: 10.2326/osj.1.117

Kozma, J. 2009. Nest-site attributes and reproductive success of White-headed and Hairy Woodpeckers along the East-slope Cascades of Washington State. - In: Rich, T. D., Thompson, C. D., Demarest, D. \& Arizmendi, D. (eds.) Tundra to Tropics: connecting birds, habitas and people. - Proceedings of the Fourth International Partners in Flight Conference, McAllen, TX., pp. 52-61.

Lammertink, M. 2014. Trends in threat status and priorities in conservation of the woodpeckers of the world. - Acta Ornithologica 49(2): 207-219. DOI: 10.3161/173484714X687109

Lindenmayer, D. B., Fischer, J., Felton, A., Crane, M., Michael, D., Macgregor, C., Montague-Drake, R., Manning, A. \& Hobbs, R. J. 2008. Novel ecosystems resulting from landscape transformation create dilemmas for modern conservation practice. - Conservation Letters 1: 129-135. DOI: 10.1111/j.1755-263X.2008.00021.x

Magura, T., Báldi, A. \& Horváth, R. 2008. Breakdown of the species-area relationship in exotic but not in native forest patches. - Acta Oecologica 33: 272279. DOI: $10.1016 /$ j.actao.2007.11.007

Martin, K. \& Eadie, J. M. 1999. Nest webs: A community-wide approach to the management and conservation of cavity-nesting forest birds. - Forest Ecology Management 115(2): 243-257. DOI: 10.1016/S0378-1127(98)00403-4
Martin, K., Aitken, K. E. H. \& Wiebe, K. L. 2004. Nest sites and nest webs for cavity-nesting communities in interior British Columbia, Canada: nest characteristics and niche partitioning. - The Condor 106(1): 5-19. DOI: 10.1650/7482

Mazgajski, T. 1998. Nest-site characteristic of Great-spotted Woodpecker Dendrocopos major in Central Poland. - Polish Journal of Ecology 46(1): 33-41.

Melletti, M. \& Penteriani, V. 2003. Nesting and feeding tree selection in the endangered Whitebacked Woodpecker Dendrocopos leucotos lilfordi. - The Wilson Bulletin 115(3): 299-306. DOI: 10.1676/03-022

Mihály, B. \& Botta-Dukát, Z. (eds.) 2004. Biológiai inváziók Magyarországon. Özönnövények [Biological invasions in Hungary. Invasive plants]. Természetbúvár Alapítvány Kiadó, Budapest (in Hungarian)

Milton, S. J. 2003. 'Emerging ecosystems': a washing-stone for ecologists, economists and sociologists? - South African Journal of Science 99: 404-406.

Ónodi, G. \& Csörgö, T. 2013. Relationship between vegetation structure and abundance of Great-spotted Woodpeckers (Dendrocopos major) in a mosaic habitat. - Ornis Hungarica 21(1): 1-11. DOI: 10.2478/orhu-2013-0011

Ónodi, G. \& Csörgö, T. 2014. Habitat preference of Great-spotted Woodpecker (Dendrocopos major Linnaeus, 1758) and Lesser-spotted Woodpecker (Dendrocopos minor Linnaeus, 1758) in the presence of invasive plant species - preliminary study. - Ornis Hungarica 22(2): 50-64. DOI: 10.2478/orhu-2014-0018

Pasinelli, G. 2007. Nest site selection in Middle and Great-spotted Woodpeckers Dendrocopos medius \& D. major: implications for forest management and conservation. - Biodiversity and Conservation 16: 1283-1298. DOI: 10.1007/s10531-0079162-x

Politi, N., Hunter, M. Jr. \& Rivera, L. 2010. Availability of cavities for avian cavity nesters in selectively logged subtropical montane forests of the Andes. - Forest Ecology and Management 260: 893-906. DOI: $10.1016 /$ j.foreco.2010.06.009

Poole, R. W. 1974. An introduction to quantitative ecology. - McGraw-Hill, New York

Porté, A. J., Lamarque, L. J., Lortie, C. J., Michalet, R. \& Delzon, S. 2011. Invasive Acer negundo outperforms native species in non-limiting resource environments due to its higher phenotypic plasticity. - BioMed Central Ecology 11: 28. DOI: 10.1186/1472-6785-11-28

Roberge, J-M., Angelstam, P. \& Villard, M-A. 2008a Specialised woodpeckers and naturalness in 
hemiboreal forests. Deriving quantitative targets for conservation planning. - Biological Conservation 141(6): 997-1012. DOI: 10.1016/j.biocon. 2008.01.010

Roberge, J-M., Mikusinski, G. \& Svensson, S. 2008b The White-backed Woodpecker: umbrella species for forest conservation planning? - Biodiversity and Conservation 17(10): 2479-2494. DOI: 10.1007/s10531-008-9394-4

Ross, W. G., Kulhavy, D. L. \& Conner, R. N. 1997. Stand conditions and tree characteristics affect quality of longleaf pine for Red-cockaded Woodpecker cavity trees. - Forest Ecology and Management 91: 141-154.

Rumble, M. A. \& Gobeille, J. E. 1998. Bird community relationships to succession in green ash (Fraxinus pennsylvanica) woodlands. - American Midland Naturalist 140: 372-381. DOI: 10.1674/0003-0031(1998)140[0372:BCRTSI]2.0. $\mathrm{CO} ; 2$

Saccone, P., Brun, J-J. \& Michalet, R. 2010. Challenging growth-survival trade-off: a key for Acer negundo invasion in European floodplains? - Canadian Journal of Forest Research 40: 1879-1886. DOI: 10.1139/X10-134

Scott, M. L., Auble, G. T. \& Friedman, J. M. 1997. Flood dependency of cottonwood establishment along the Missouri river, Montana, USA. - Ecological Applications 7(2): 677-690. DOI: 10.1890/1051-0761(1997)007[0677:FDOCEA]2.0.CO;2

Smith, K. W. 1995. Nest site selection of the Great-spotted Woodpecker Dendrocopos major in two oak woods in southern England and its implications for woodland management. - Biological Conservation 80: 283-288. DOI: 10.1016/S00063207(96)00038-9

Smith, K. W. 1997. Nest site selection of the Great-spotted Woodpecker Dendrocopos major in two oak woods in Southern England and its implications for woodland management. - Biological Conservation 80: 283-288.

Smith, K. W. 2007. The utilization of dead wood resources by woodpeckers in Britain. - Ibis
149(Suppl.2): 183-192. DOI: 10.1111/j.1474919X.2007.00738.x/

Starzomski, B. M. 2013. Novel ecosystems and climate change. - In: Hobbs, R. J., Higgs, E. S. \& Hall, C. M. (eds.) Novel ecosystems. Intervening in the new ecological world order. - Wiley-Blackwell, Chichester, pp. 88-101.

Udvardy, L. 2008. Boxelder (Acer negundo L.). - In: Botta-Dukát, Z. \& Mihály, B. (eds.). The most important invasive plants in Hungary. Institute of Ecology and Botany, Hungarian Academy of Sciences, Vácrátót, Hungary, pp. 115-120.

Vaillancourt, M., Drapeau, P., Gauthier, S. \& Robert, M. 2008. Availability of standing trees for large cavity-nesting birds in the eastern boreal forest of Québec, Canada. - Forest Ecology and Management 255: 2272-2285.

van Turnhout, C. A. M., Leuven, R. S. E. W., Hendriks, A. J., Kurstjens, G., van Strien, A., Foppen, R. P. B. \& Siepel, H. 2010. Ecological strategies successfully predict the effects of river floodplain rehabilitation on breeding birds. - River Research and Applications 28(3): 269-282. DOI: 10.1002/rra.1455

Wan, T., Hu, J., Jiao, Z., Wen, J. \& Luo, Y. 2008. Nest-cavity characteristics of the Great-spotted Woodpecker Dendrocopos major in shelter plantations of west Inner Mongolia. - Forestry Studies in China 10(1): 36-40. DOI: $10.1007 / \mathrm{s} 11632-$ 008-0010-1

Walankiewicz, W. \& Czeszczewik, D. 2005. Wykorzystanie osiki Populus tremula przez ptaki w drzewostanach pierwotnych Białowieskiego Parku Narodowego [Use of aspen Populus tremula by birds in primeval stands of the Białowieża National Park]. - Notatki Ornitologiczne 46: 9-14. (in Polish with English Summary)

Wesołowski, T. \& Tomiałojć, L. 1986. The breeding ecology of woodpeckers in a temperate primaeval forest - preliminary data. - Acta Ornithologica 22: 1-21.

Wesolowski, T. 2007. Lessons from long-term hole-nester studies in a primeval temperate forest. - Journal of Ornithology 148: 395-405. DOI: 10.1007/s10336-007-0198-1

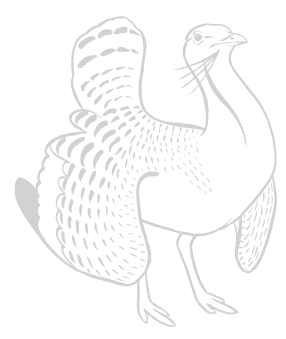

